Ana Patrícia Rodrigues Domingues ${ }^{1}$

ADRIANA BELO ${ }^{2}$

Paulo MOURA ${ }^{1,3}$

DuARTE NUNO VIEIRA ${ }^{4}$

\title{
Medico-legal litigation in Obstetrics: a characterization analysis of a decade in Portugal
}

\author{
Litígio médico-legal em Obstetrícia: \\ caracterização de uma década em Portugal
}

Original Article

Keywords

Jurisprudence

Forensic Medicine

Asphyxia neonatorum

Cesarean section/adverse effects

Palavras-chave

Jurisprudência

Medicina Legal

Obstetrícia

Asfixia neonatal

Cesária/efeitos adversos
Abstract

PURPOSE: It was to analyse the most critical areas in Obstetrics and to suggest measures to reduce or avoid the situations most often involved in these disputes. METHODS: Obstetrics cases submitted to the Medico-legal Council since the creation of the National Institute of Legal Medicine and Forensic Sciences in 2001 until 2011 were evaluated. A comprehensive characterization, determination of absolute/relative frequencies, hypothesis of a linear trend over the years and the association between each parameter was done. RESULTS: The analysis has shown no significantly linear trend. The most common reasons for disputes were perinatal asphyxia (50\%), traumatic injuries of the newborn (24\%), maternal sequelae (19\%) and issues related to prenatal diagnosis and/or obstetric ultrasound (5.4\%). Perinatal asphyxia showed no significantly linear trend ( $p=0.58$ ) and was usually related to perinatal deaths or permanent neurologic sequelae in newborn children. Traumatic injuries of the newborn, mostly related to instrumented deliveries, shoulder dystocia or vaginal delivery in breech presentation, has shown a significantly increased linear trend ( $<<0.001)$, especially related to instrumented deliveries. The delay/absence of cesarean section was the clinical procedure questioned in a significantly higher number of cases of perinatal asphyxia $(68.7 \%)$ and of traumatic lesions of the newborn due to instrumented deliveries $(20.5 \%)$. CONCLUSION: It is important to improve and correct theoretical/practical daily clinical performance in these highlighted areas, in order to reduce or even avoid situations that could end up in medico-legal litigations.

\section{Resumo}

OBJETIVO: Foi analisar as áreas mais críticas em Obstetrícia e sugerir medidas para reduzir ou evitar as situações mais frequentemente envolvidas nessas disputas. MÉTODOS: Foram avaliados todos os casos relativos à Obstetrícia apresentados ao Conselho Médico-legal desde a criação do Instituto Nacional de Medicina Legal e Ciências Forenses em 2001, até 2011 . Foi efetuada uma análise compreensiva, determinação de frequências absolutas/relativas, hipótese de linear trend ao longo dos anos e a associação entre os diversos parâmetros. RESULTADOS: As razões mais comuns para o litígio foram a asfixia perinatal (50\%), as lesões traumáticas do recém-nascido (24\%), as sequelas maternas (19\%) e questões relacionadas com o diagnóstico pré-natal e/ou ecografia obstétrica (5,4\%). A asfixia perinatal não teve qualquer tendência linear ao longo dos anos $(p=0,58)$ e esteve geralmente relacionada a mortes perinatais ou sequelas neurológicas permanentes nos recém-nascidos. As lesões traumáticas do recém-nascido, principalmente relacionadas com partos instrumentados, distócia de ombros ou parto vaginal em apresentação pélvica, mostrou uma tendência linear de aumento significativo ao longo dos anos $(p<0,001)$, especialmente relacionada com a instrumentação dos partos. $\bigcirc$ atraso/ausência de cesariana foi o procedimento clínico questionado num número significativamente maior de casos de asfixia perinatal $(68,7 \%)$ e de lesões traumáticas do recém-nascido devido a partos instrumentados (20,5\%). CONCLUSÃO: É importante melhorar e corrigir o desempenho teórico/prático da clínica diária nas áreas destacadas, a fim de reduzir ou mesmo evitar situações que poderão levar a litígio médico-legal em obstetrícia.
Correspondence

Ana Patricia Rodrigues Domingues Maternidade Dr. Daniel de Matos Centro Hospitalar e Universitário de Coimbro Rua Miguel Torga CEP: 3030-165 Coimbra, Portugal

Received 02/11/2015

Accepted with modifications 04/07/2015
Obstetric Service A of Maternidade Dr. Daniel de Matos of Centro Hospitalar e Universitário de Coimbra; Faculdade de Medicina da Universidade de Coimbra - Coimbra, Portugal.

'Obstetric A, Maternidade Daniel de Matos, Centro Hospitalar e Universitário de Coimbra - Coimbra, Portugal.

2Biostatistics, Universidade de Coimbra - Coimbra, Portugal

${ }^{3}$ Obstetric Clinic, Faculdade de Medicina, Universidade de Coimbra - Coimbra, Portugal.

${ }^{4}$ Faculdade de Medicina, Universidade de Coimbra - Coimbra, Portugal.

Conflict of interests: none. 


\section{Introduction}

Obstetrics has great relevance in the court of medical liability, and is the target of intense debate, especially in American literature ${ }^{1-4}$. Added to a more traditional litigation situations (e.g., perinatal asphyxia) new potentially litigious areas are now emerging, examples of which are prenatal diagnosis and decisions in MaternalFetal Medicine ${ }^{5,6}$.

With recent technological and clinical advances, the general public has acquired a high expectation of favorable results, considering that any deviation from this expectation must be someone's responsibility, usually of the physician and/or staff who provided assistance. They do not take into account (nor it is released when there is media coverage of these cases) the individual biological variations or that technology itself has its limits.

As a result of these complaints, and facing the threat of professional liability cases, many doctors change their clinical attitude to a defensive medicine practice, whose exercise may not always be beneficial to the patient, by prescribing unnecessary exams or even by giving up or avoiding areas of activity more susceptible to litigation. The knowledge that most health professionals have on this issue is the result of the America's circumstances dissemination, where the problem of Medical Liability is present in day-to-day professional routine and has dramatic consequences at the level of daily activity and on professional choices. It is a situation that exists for a few decades and led to the escalation of insurance premiums which become a threat to the obstetric practice ${ }^{1-15}$.

In Europe, the awareness to the possibility of medicolegal prosecution against doctors is a recent phenomenon, with few studies on the topic. There is no notion of the real scale of the problem, nor of the possible consequences in professionals' daily clinical practice ${ }^{7,9-11,16}$. In Portugal, although there are some studies on Medical Liability in general and in other specialties, there has been none on Obstetrics in particular, besides the already developed by the author in $2007^{17-19}$.

Given that Obstetrics is one of the most affected medical specialty in medical liability suits and given its consequences in daily clinical practice, it is important to assess the Portuguese circumstances concerning situations of medico-legal dispute in this area.

The objective of this study was to identify the most critical areas in Obstetrics, their evolution over a decade and the clinical procedures related to it, in order to suggest strategies that could reduce or avoid the situations most often involved in these disputes. To achieve this purpose, Obstetrics cases submitted to the Medico-legal
Council since the creation of the National Institute of Legal Medicine and Forensic Sciences in 2001 until 2011 were evaluated.

\section{Methods}

The review and study of the cases of medical liability examined in the Medico-legal Council between 2001 and 2011 was performed. This analysis was carried out after formulating an application to consult the files to the president of the Directing Council of the National Institute of Legal Medicine and Forensic Sciences, which was accepted.

All obstetrical cases submitted during that period were included. The analysis was performed by drawing a computerized grid on which the origin event described in the technical-scientific opinion of each file was recorded, as well as the medical/clinical intervention that culminated in the disputed event, when applied.

We performed a comprehensive characterization of the sample. All parameters were characterized by the determination of absolute and relative frequencies. The relative frequency of each cause for prosecution and of each medical intervention that led to the complaint was determined per year. The annual change was graphed and the test of the hypothesis of a linear trend in relative frequency over the years was performed using the $\chi^{2}$ test for trend.

The association between each parameter of influence in medical intervention and each ground of the complaints was evaluated by using the $\chi^{2}$ test.

The level of significance used in this analysis was $5 \%$. The statistical software SPSS ${ }^{\circledR}$ v19.0.0.2 was used.

\section{Results}

Of the total 1,261 cases analyzed, 212 were selected regarding the specialty of Obstetrics/Gynecology. Of these, 168 were related to Obstetrics.

Of all cases submitted to Medico-legal Council appreciation in the period analyzed, Obstetrics and Gynecology was the second most frequent medical specialty contested, following Internal Medicine. Obstetrics cases only (without those referring to Gynecology complaints) account for the third place.

The number of cases over the years did not undergo major variations despite a peak in 2008 (Figure 1). Of the 168 Obstetrics cases analyzed, the causes found were grouped into 5 most frequent categories (in decreasing order): perinatal asphyxia (50\%), traumatic lesions in the newborn (24.4\%), maternal sequelae $(19 \%)$, prenatal diagnosis/obstetric ultrasound $(5.4 \%)$ and others $(1.2 \%)$. 
As for their evolution over the years, there was no significantly linear trend for perinatal asphyxia $(\mathrm{p}=0.5)$, maternal sequelae $(\mathrm{p}=0.8)$ or prenatal diagnosis $(\mathrm{p}=0.43)$, and there was a significant increase for traumatic sequelae of the newborn $(\mathrm{p}<0.001)$. The perinatal consequences that caused complaints of perinatal asphyxia resulted from sequel or permanent neurologic damage in $26 \%$ of the cases and/or in perinatal death in $74 \%$. Over the years there has been a significant increase in the occurrence of neurologic sequelae, but no significantly linear trend was found for perinatal death (Figure 2).

The group of traumatic lesions of the newborn includes three subgroups of events: instrumented deliveries (39\%), with an increase linear tendency over the years $(\mathrm{p}<0.001)$; shoulder dystocia $(43.9 \%)$; and vaginal delivery in breech presentation (17\%), whose frequencies and linear trend are showed in Figure 2.

The circumstances that led to the establishment of the 32 maternal sequels processes were uterine hemorrhage requiring hysterectomy in $59.4 \%$, maternal death (following hemorrhagic complications) in $25 \%$, and surgical complications (arising from caesarean) and bilateral tubal ligation (per-caesarean without consent) in $15.6 \%$.

The 9 cases involving issues of prenatal diagnosis of fetal anomalies refer to situations in which the obstetric ultrasound was questioned by the misdiagnosis of fetal malformations or genetic alterations. The remaining cases were related to medical and/or surgical complications of abortions performed in pregnancy. Due to their small number, these cases were not included in the subsequent analyses.

Clinical approaches or medical interventions contested were lateness/absence in performing a caesarean delivery in $50 \%$ of cases, no appraisal of complaints and/or exams in $28 \%$, and instrumentation of deliveries in $22 \%$. Over the years, regarding the occurrence and distribution of these interventions, there was a significant increase of the delay/absence of caesarean section $(p=0.04)$ and of the non-appraisal of complaints/tests $(\mathrm{p}=0.03)$, but no significant linear trend over the years was seen for instrumentation of deliveries $(\mathrm{p}=0.65)$.

The distribution of clinical approaches contested in the complaints for each cause (and taking into account

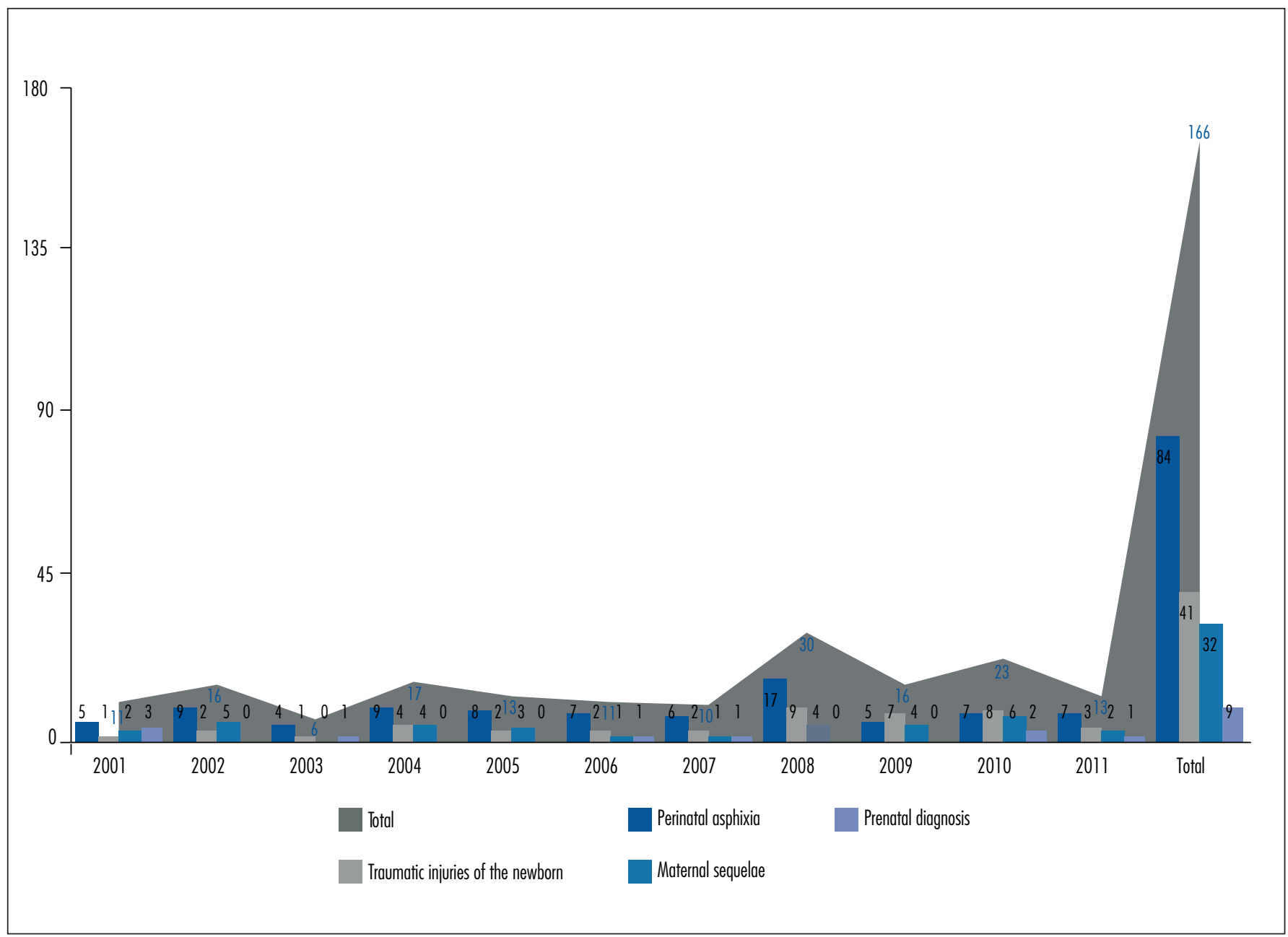

Figure 1. Obstetrical situations leading to prosecution in medico-legal cases during the 11 years period (total and major causes per year). 
that each cause can be contested in more than one intervention) is summarized in Table 1.

The delay/absence in caesarean section was questioned in $68.7 \%$ of complaints from perinatal asphyxia, a significantly higher number than in the others clinical approaches (especially regarding neurological sequelae in newborns $-24.3 \%$ ). Also, traumatic lesions of the newborn caused by instrumented deliveries (20.5\%) and shoulder dystocia (17.8\%) led to significantly more complaints of delay/absence in caesarean section than others approaches. Cases of women who questioned instrumentation of deliveries had significantly higher complaints of perinatal asphyxia than those who questioned the no appraisal of complaints/exams (32.1 versus $25.3 \%)$.
Table 1. The distribution of clinical approaches contested in the complaints for each cause

\begin{tabular}{|c|c|c|c|}
\hline & $\begin{array}{l}\text { Instrumentation } \\
\text { of deliveries (\%) }\end{array}$ & $\begin{array}{l}\text { Delay/absence } \\
\text { of cesarean (\%) }\end{array}$ & $\begin{array}{c}\text { No appraisal of } \\
\text { complains/exams (\%) }\end{array}$ \\
\hline Perinatal asphyxia & $32.1^{\star \star}$ & $68.7^{\star \star}$ & 25.3 \\
\hline Neurologic sequelae & 15.2 & $24.3^{\star \star}$ & 16.7 \\
\hline Perinatal death & 45.5 & 48.6 & 54.8 \\
\hline \multicolumn{4}{|l|}{$\begin{array}{l}\text { Traumatic lesions } \\
\text { of newborn }\end{array}$} \\
\hline $\begin{array}{l}\text { Instrumented } \\
\text { deliveries }\end{array}$ & 48.5 & $20.5^{\star \star}$ & $2.4^{\star}$ \\
\hline $\begin{array}{l}\text { Vaginal breech } \\
\text { delivery }\end{array}$ & 0 & 4.1 & 4.8 \\
\hline Shoulder dystocia & 21.2 & $17.8^{\star}$ & 4.8 \\
\hline Maternal sequelae & 9.1 & $8.8^{\star \star}$ & 16.7 \\
\hline Prenatal diagnosis & Not applicable & Not applicable & 4.8 \\
\hline
\end{tabular}

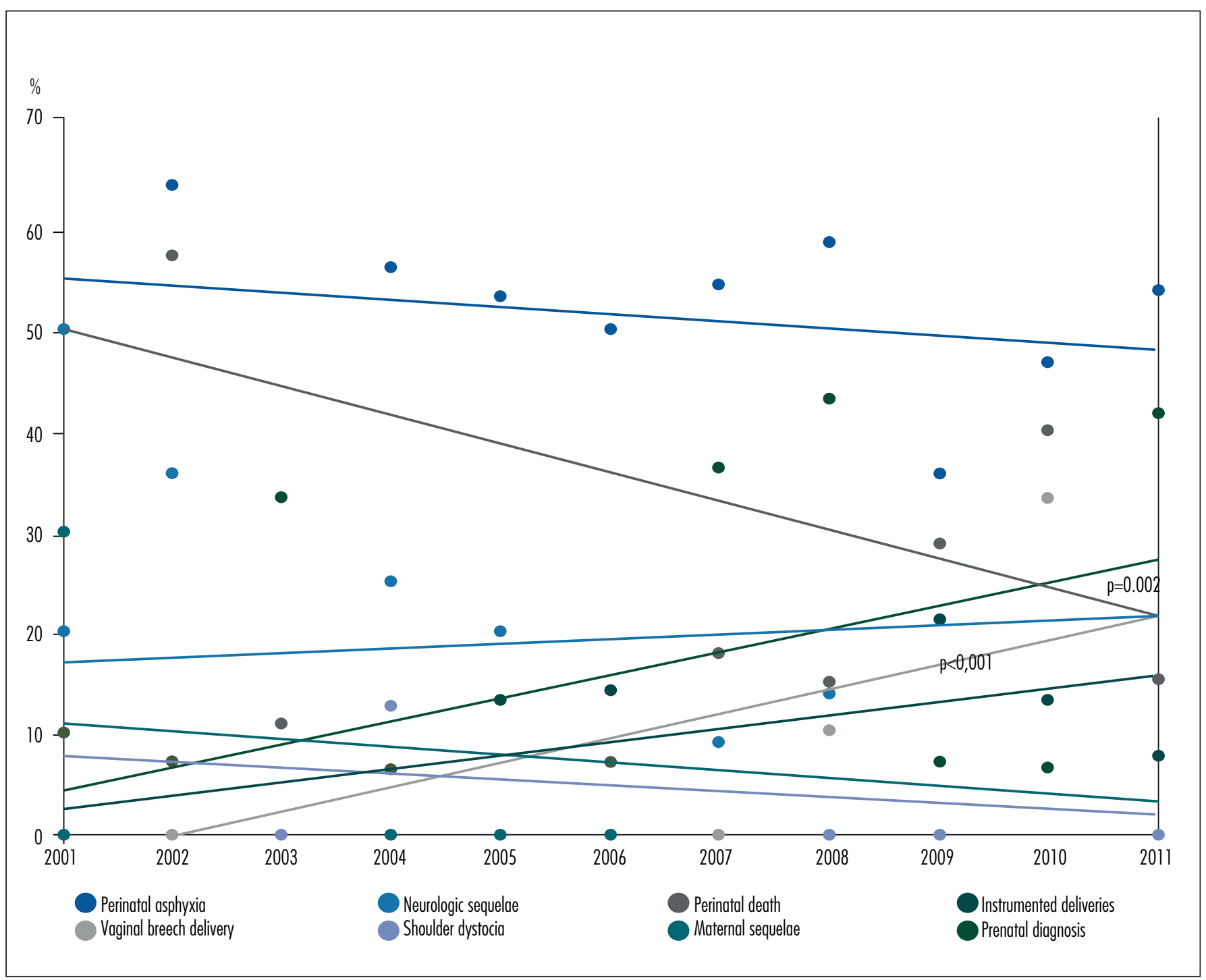

Figure 2. Frequency and linear trend of the most common causes of Obstetrics litigation. 


\section{Discussion}

The objective of identifying the most critical areas in Obstetrics, their evolution over a decade and the clinical procedures related to them was fulfilled with the study results.

We observed that Obstetrics/Gynecology was the second most prevalent specialty. The annual caseload of medical liability in Obstetrics did not have a significant linear trend over the years, a fact we assume to be related to the increase practice of defensive medicine admitted by half of Portuguese specialists and/or to cases progressing in other instances (Disciplinary Council of the Medical Order and courts) that have not yet arrived, or will not arrive at the Medico-legal Council ${ }^{17,18}$.

The most common cause of litigation in Obstetrics was perinatal asphyxia, classically regarded as the most frequent reason for Medical Liability prosecution in Obstetrics and usually related with intrapartum fetal deaths or permanent neurologic sequelae in newborns. Indeed, the complaints of neurologic sequelae in infants showed, in our sample, a significant increasing trend as a matter of dispute during the last decade.

Concerning delivery, the most controversial issues are the screening and diagnosis of perinatal asphyxia, the instrumented extractions in high risk situations (cases of macrosomia and breech) and the practice of caesarean section ${ }^{5}$. In this study, we found a significantly higher number of cases of perinatal asphyxia when instrumented deliveries and/or delay/absence of a caesarean section were questioned, reflecting what we see in daily clinical practice - any complications or sequelae in the newborn after the occurrence of a vaginal birth leads parents to question the procedure and the existence of those complications/sequelae with alternative procedures, usually caesarean delivery.

Traumatic injuries of the newborn, related with instrumented deliveries, shoulder dystocia and vaginal delivery in breech presentation, appeared as second more frequent causes. There was a rise in the frequency of this litigation cause primarily related to instrumented deliveries, which currently assume a previously nonexistent importance and a significant increasing trend in the last four years ${ }^{17,18}$. In cases of vaginal delivery in breech presentation, there was no significantly higher complains questioning medical interventions, which probably is related to their small number. However, when traumatic injuries of newborns were questioned as a result of the delay/absence in a caesarean section, there was a significantly higher number of cases of instrumented deliveries and/or shoulder dystocia, an unsurprising fact for the reason discussed above.
The third most frequent reason for disputes in Obstetrics, occupied by maternal sequelae, continues to be a surprise, since this is not a relevant reason for dispute in the international literature. This result may reflect the still scarce volume of medico-legal proceedings in Portugal. To be noted is the fact that the majority of cases $(60 \%)$ results from the occurrence of postpartum bleeding leading to hysterectomy and/or maternal deaths.

Prenatal diagnosis, mostly due to issues related to obstetric ultrasound, comes in fourth place. This result does not reflect the high importance that health professionals in the area give to it nor international circumstances and may result from the fact that cases of this particular area do not reach the Medico-legal Council or are filed and resolved in other courts $5,17,18$. The incorporation of ultrasound in prenatal diagnosis and the involvement of obstetricians in their daily performance have led to a greater risk exposure of such litigation ${ }^{4}$.

The technical-scientific opinions emitted by the Council regarding each case and the influence of the clinical files quality on these conclusions was reported and commented elsewhere $\mathrm{e}^{20,21}$.

For the evaluation of the national situation of Obstetrical medical liability, it was important to analyze these cases referred to the Medico-legal Council. It is for the Medico-legal Council, among other functions, to exercise functions of technical and scientific advice and to advise on technical and scientific expertise in the field of legal medicine and other forensic sciences issues. The Medico-legal Council is formed by: the chairman of the directive council of the National Institute of Legal Medicine and Forensic Sciences, the vice president and the vocals, a representative of the regional disciplinary boards of each regional section of the Medical Association, two university teachers of each scientific fields of clinical surgery, Internal Medicine, Obstetrics and Gynecology, and law; a university professor of each of the following scientific areas: Pathology, Ethics and/or Medical Law, Orthopedics and Traumatology, Neurology, Neurosurgery and Psychiatry. When necessary, it may be requested the cooperation of teachers of other subjects or other higher education institutions, as well as experts of recognized merit. The technical and scientific opinion can be requested by a member of the Government responsible for justice, by the Supreme Judicial Council, by the Attorney General's Office or by the chairman of the directive council of the National Institute of Legal Medicine and Forensic Sciences.

Although it probably represents many of the judicial proceedings in the area of Medical Liability, it does not represent all proceedings, especially those 
in Civil and Disciplinary Law, which are often analyzed in another judicial place and not remitted to the Medico-legal Council. It probably represents the tip of the iceberg, but it indicates the Portuguese circumstances in this particular area.

All cases evaluated report situations that require the involvement of the various healthcare professionals who work in Obstetrics and the full knowledge of the procedures/maneuvers which are possible to apply in order to resolve these obstetric problems. Given the unpredictability of the occurrence or difficulty of resolving situations like shoulder dystocia, an instrumented or breech delivery, or a postpartum bleeding, constant theoretical and practical training/revision and updating of all health professionals is imperative. These situations correspond to obstetric emergencies which are acute complications that endanger the life of the mother and/or fetus. Since they are sometimes rare situations, there are therefore few opportunities for real training, and we return to the need of encouraging professionals in this area to carry out training in order to minimize inappropriate care arising from inexperience, indecision and lack of coordination of teamwork. This continuous training of health professionals in Obstetrics can be done by Simulation of Medical scenarios, which may help obstetrics health care professionals to reduce or avoid the number of conflict situations that lead to medico-legal issues.

This work elucidates obstetrics professionals of national reality (even that only for a selected part of it) concerning Obstetrics litigation. The most frequent complaints are related to perinatal asphyxia and traumatic lesions of the newborn, and the delay/ absence of cesarean section and the instrumentation of deliveries are the clinical procedures questioned in a significantly higher number of cases. With the final objective of reducing or even avoiding situations that could end up in medico-legal litigations, this knowledge is essential to all professionals in order to improve and correct their theoretical and practical daily clinical performance in these highlighted areas, which they can do by constant theoretical and practical training/revision and updating either in meetings or in scenarios of medical simulation.

\section{References}

1. Frigoletto FD, Greene MF. Is there a sea change ahead for obstetrics and gynecology? Obstet Gynecol. 2002;100(6):1342-3.

2. Howard PK. Is the medical justice system broken? Obstet Gynecol. 2003; 102(3):446-9.

3. Queenan JT. Professional liability crisis: a road map to success. Obstet Gynecol. 2004; 104(3):429-30.

4. Hammond CB, Schwartz PA. Ethical issues related to medical expert testimony. Obstet Gynecol. 2005;106(5 Pt 1):1055-8.

5. Owolabi T, Farinei D, Bell D, Davis D, Knickle DA, Milne K, et al. Providing opinion for medico-legal cases. J Obstet Gynaecol Can. 2002;24(7):590-5.

6. Mavroforou A, Mavrophoros D, Koumantakis E, Michalodimitrakis E. Liability in prenatal ultrasound screening. Ultrasound Obstet Gynecol. 2003;21(6):525-8.

7. Dubay L, Kaestne R, Waidmann T. Medical malpractice liability and its effect on prenatal care utilization and infant health. J Health Econ. $2001 ; 20(4): 591-611$.

8. Hammond CB. The decline of the profession of medicine. Obstet Gynecol. 2002;100(2):221-5.

9. MacLennan AH, Spencer MK. Projections of Australian obstetricians ceasing practice and the reasons. Med J Aust. 2002; 176(9):425-8.

10. Kravitz RL, Leigh JP, Samuels SJ, Schembri M, Gilbert WM. Tracking career satisfaction and perceptions of quality among US obstetricians and gynecologists. Obstet Gynecol. 2003;102(3):463-70.

11. Bettes BA, Strunk AL, Coleman VH, Schulkin J. Professional liability and other career pressures: impact on obstetrician-gynecologists' career satisfaction. Obstet Gynecol. 2004;103(5 Pt 1):967-73.
12. Chan BT, Willett J. Factors influencing participation in obstetrics by obstetrician-gynecologists. Obstet Gynecol. 2004;103(3):493-8.

13. Laros RK. Presidential address: medical-legal issues in obstetrics and gynecology. Am J Obstet Gynecol. 2005;192(6): 1883-9.

14. Pearlman MD, Gluck PA. Medical liability and patient safety: setting the proper course. Obstet Gynecol. 2005; 105(5 Pt 1):941-3.

15. Queenan JT. Professional liability insurance: still a crisis. Obstet Gynecol. 2005;105(6):1285-6.

16. Committee on Professional Liability, American College of Obstetricians and Gynecologists. ACOG Committee Opinion \#309: coping with the stress of medical professional liability litigation. Obstet Gynecol. 2005;105(2):453-4.

17. Domingues AP. Responsabilidade profissional no âmbito da prestação de cuidados de saúde em obstetrícia/ginecologia: análise da situação actual e da perspectiva dos profissionais de saúde [dissertação]. Coimbra: Universidade de Coimbra; 2007.

18. Domingues AP, Cordeiro C, Moura P, Vieira DN. Responsabilidade médica em ginecologia/obstetrícia: perspectiva portuguesa. Acta Obstet Ginecol Port. 2009;3(1):24-34.

19. Moreira H, Magalhães T, Dinis-Oliveira R, Taveira-Gomes A. Forensic evaluation of medical liability cases in general surgery. Med Sci Law. 2014;54(4):193-202.

20. Domingues AP, Moura P, Vieira DN. Lessons from a decade of technical-scientific opinions in obstetrical litigation. J Forensic Leg Med. 2014;25:91-4.

21. Domingues AP, Moura P, Vieira DN. Obstetric litigation: the importance of the quality of clinical files and its influence on expertise conclusions. J Obstet Gynaecol. 2015;35(2): 146-9. 